\title{
Shelter at a Police Colony
}

My sister and I, weakened and totally exhausted, just drifted aimlessly after we were freed, not knowing or caring where we went so long as it was as far as possible from the Warsaw inferno. We were penniless, with nowhere to go and no one to turn to for help. We just trudged from field to field and farmstead to farmstead that day, getting the same brush-off from surly farmers wherever we went. Glancing over our shoulders, back towards the capital, we could see a huge pall of black smoke suspended in the sky above the blazing city like a giant mushroom, with a hazy pink glow below it. Although it was a fine sunny day, the sun was almost blotted out. We could see in the distance terrifying Stuka dive-bombers in action over the capital with their screaming sirens, repeatedly diving in and out, pulverising whatever parts of the city were still holding out. We found out later that by the time it was over, more than 200,000 people had been killed, mostly non-combatants, out of a population of just over a million, with thousands more wounded.

We realised just how fortunate we were to have come through unscathed, apart from some minor scratches, particularly as we had been caught in the heat of battle by crazed SS-Dirlewanger troops. This ragtag SS brigade consisted of convicts largely recruited from German prisons. They were in the main hardened criminals who had earlier committed terrible atrocities when stationed in Russia. Based on information obtained later, the Poles estimated that the Dirlewanger brigade, named after its commander, who was one of Hitler's favourite officers, in an orgy of savagery against the civilian population killed between forty and fifty thousand innocent people within a matter of days in our district of Wola and nearby Ochota alone. They were assisted in their brutality by the Kaminski brigade, consisting of Lithuanians and Ukrainians who had switched to the German side. The Dirlewanger thugs were withdrawn by the German high command after the carnage in Wola, perhaps because the riff-raff had indulged in rape and pillage. To Nazi logic it was quite 
acceptable to kill thousands of innocent civilians, aber Ordnung muss sein-Germanic order and iron discipline must prevail.

Those who survived the uprising and were not deported to Germany tried to find shelter with relatives and friends outside of Warsaw. Later on, evacuees were sent to a selection camp at Pruszków, outside Warsaw, where they were segregated. The young and fit were sent to Germany for forced labour, the elderly, as well as women with children, were released. Unlike the others, we had no relatives or friends to turn to for help or accommodation. We were as we stood, with only the grimy clothes on our backs, and nothing to live on. The only thing I still had and held onto at all cost was my birth certificate and the vital "magic glue." But unfortunately Wala had never had her stolen identity papers replaced after her miraculous escape from the clutches of the Gestapo. This would immediately put her under suspicion in the event of a random identity check in the street, but now at least she had a more plausible explanation for what had happened to them: they were "destroyed or lost during the uprising."

We trekked from place to place like the eternal Wandering Jewwas this perhaps what Wanda in Anin had meant by, "Jews are doomed to wander the earth for their sins until Judgment Day"? And all the time the oppressive sun kept beating down-it was a particularly hot August that year. We looked for shelter along the way, living on what we could find in the fields. My sister could have taken on temporary work as a farm-hand or domestic helper were it not for me. She was prepared to forego pay in exchange for a roof over our heads, but for two of us it was difficult. Food was in short supply, and nobody wanted an extra mouth to feed, even on a farm. At least we now had a good excuse for being homeless, as there were so many other displaced people from Warsaw. But I was the problem, and a burden to Wala. This preyed on my mind: I didn't like to be a strain on my sister. We needed to quickly find a place where I could be kept out of sight, or perhaps work as a farm-boy, which would have provided good cover for me. But that seemed impossible for a young boy: farmers and villagers were a curious lot, not very welcoming and rather suspicious of strangers.

Just as our situation seemed utterly hopeless, Wala had a brainwave. She vaguely remembered that Bolek Piatkowski, who had so kindly offered us refuge in his home, had mentioned that he had a summer-house near a lake in some sort of holiday colony. It may have been in the vicinity of Błonie, she thought, but I cannot be sure of the name now. I do 
know it was some distance west of the capital. The Piatkowskis had sent their children there for the summer vacation for safety in the event of an uprising, which they must have been anticipating. We trudged along slowly for a couple of days until we finally reached the place. We were very surprised to discover that it was indeed a holiday colony, and was specifically meant for Polish policemen, of all people, who either owned or had the use of these holiday chalets. They were all identical log cabins built around a pond, off the beaten track, in an isolated picturesque setting surrounded by pine trees.

It immediately dawned on us that from our point of view the place would be ideal for us. If we could only stay there, it would provide us with excellent cover. The safest places were often right inside the lion's den! The Polish police collaborated with the Gestapo, insofar as Jews were concerned, and the general population held no great affection for the Polish "Blue" police-not because of their hostile attitude to Jews, but because they were corrupt and served the enemy. Here, we thought, we would be way beyond suspicion; it would never occur to anyone to go looking for Jews inside a police colony. Wala started to ask around for the Piatkowski cabin, which we soon located. Three of the Piatkowski children were there: the eldest, a boy, who was a little older than I, and his two younger sisters. Their mother, whom we had last seen in Warsaw, had not so far appeared. We had gotten separated from her during the turmoil when we'd fled the blazing building. My sister tried to reassure the anxious children that their mother would return safely, as women were slowly being released, and the children had seen Wala in their Warsaw home, so they didn't consider her a stranger, and were calmed by her. We really thought that now we had it made. If only we could remain in the relative safety of the colony, with Wala helping to look after the children, we would be all right. The people in the colony were largely made up of wives and families of Warsaw policemen, with their husbands presumably caught up in the uprising and thus trapped in the capital.

The next morning an off-duty policeman dressed in civvies who was staying in an adjoining chalet started to look in my direction as I was playing in a sandpit with other children, all of them younger than me. Although I didn't look my age, I was a little too old to play in a sandpit, but I wanted to befriend the children, blend in, and play with them, so 
as not to stand out. I became aware that the man was observing me-it had to be me he was interested in, as he must have known the other children. Hinting that I needed to go to the lavatory, I left the others and I ran inside the cabin. In a panic, I quickly reached for the glue and ran to the toilet to take the necessary precaution.

Afterwards, I decided not to rejoin the other children, and remained indoors, as Wala had meanwhile left the colony to try to get a little food from a farm. It was a hot afternoon and the windows were wide open. After a while, the policeman came over, put his head through, and began to fire questions at me: what was my name, from where had I come, how was I connected with Bolek Piatkowski, and so on. I had to think quickly; this time I had no story prepared. I went on to explain that Wala and I had been sent by Bolek, who had joined the uprising, to take care of his children, and that we had been bombed out of his home. Surprisingly, he didn't ask about my relationship to Wala, and I didn't say she was my sister. If we were ever asked, our plan was to say that she was my cousin; this would help to explain the family resemblance. Before I had time to answer all of his questions, he cut me off and accused me of being Jewish! He was obviously not going to be convinced by any of my explanations. I was stunned; he never even gave me a chance to explain. He quickly hurried around the corner to the front door and barged in, making straight for me. Without too much ado, he pulled my trousers down with one firm tug. Having taken a good look, he said, "There is no place here for a $\dot{Z} y d e k !$ " and then vanished as quickly as he had come. I was shocked. He had, it seemed, detected that I was circumcised in spite of the disguise which had worked so well until then!

I remained indoors, at my wits' end, impatient for Wala to come back so we could run away together. When my sister finally turned up, I was beside myself as I tried to explain what had happened, and burst into tears, feeling guilty that I had let her down so badly. The episode demonstrated once more that I was a liability and a danger to her. I knew that I was a burden, and it was this that brought on the tears. I was not one to cry easily, but I felt responsible for endangering my sister, who would have done anything for me, come hell or high water. I would have preferred to go away somewhere and not come back rather than harm her in any way.

We immediately decided to make a run for it, but before we could do so, the policeman came back, having noticed that Wala had meanwhile returned. He again barged into the cabin without knocking, and he 
immediately accused her outright of harbouring a "Jew-boy." Pointing at me, he raised his voice and blurted out crudely, "He may not have had the 'ritual slash' but he's a Żydek just the same. You must be getting well paid for this one. Who is he, the son of a Warsaw physician or some big-shot lawyer? How much are the Yids paying you?," he sneered.

Wala, seeing that he'd gone in the wrong direction, found the confidence to pile abuse on him in the best Polish tradition. "Psiakrew, skurwysynie"-Dog's blood, you son of a whore!, she began. "Are you out of your mind? The boy is my brother, and how dare you call me a bleeding Jew!" The bluster was deliberate, as no Jew should have had the audacity to address any Pole in this way, let alone a police officer. The "Navy-Blue" calmed down a little, but still wouldn't let go, insisting that "the lad is Jewish." He claimed that certain lapsed Jews didn't practice circumcision. At long last, he turned and made for the door, without saying what his intentions were.

Luckily, it had never occurred to the blockhead that we might be brother and sister. Apart from the hair colouring, there was a strong family resemblance. With his mind firmly fixed on the money, he had failed to make the connection. He was so cocksure that he never asked to see our documents. He was only interested in Wala, because he thought there was money involved. My sister had no documents anymore, and as we had no pay-off money to offer we were afraid he wouldn't hesitate to hand me over to the Gestapo. We immediately abandoned the colony and the Piatkowski children, without even saying goodbye, in case the policeman grasped the situation. I was the first to slip away, followed by my sister a little while later. She knew in which direction I would head, and she caught up with me when she was able to leave. The children must have been bewildered when they got back inside to find we were gone. We felt terrible about deserting them in this way; their parents might not have made it out of Warsaw, and we could have at least helped to take care of them. We felt bad about deserting a loyal friend. On the other hand, we were a source of danger to Bolek's children and perhaps they would be better off without us. We took to the fields once more, and just ran and ran, not daring to look back in case he had sent the Gestapo after us.

While we were fleeing from Błonie, it crossed our mind that the "Blue" must have been a seasoned Warsaw shmaltzovnik, and this would not have been his first attempt at blackmail. If he'd simply wanted to 
turn me in, he could have done so then and there and just dragged me to the police station, or called the Gestapo to come and get me. Instead, he used the tactics of an extortionist, working up towards a bribe by bringing up the subject of money without actually asking for a share of it at this stage. He was sure Wala was not Jewish, and was getting well paid for taking care of me. He merely fired the first shot with the intention of laying his hands on the money and possibly turning me in later or, at best, chasing me off the colony. There was no point in trying to convince him otherwise, the only thing to do in the circumstances was to make a run for it. It was a real shame; we thought we had found the ideal sanctuary which would have afforded us excellent cover from the Gestapo.

We spent the night out in the open in some bushes. By morning we started to walk aimlessly in the oppressive August heat. It hadn't rained since the day we were trapped in the AK foxhole during the uprising. We just trudged along, not knowing or caring where we were heading. We lived on what we could find in the fields and slept out in the open. Finding drinking water became a problem, and we needed it desperately in the intense shimmering heat that rose from the fields and dusty paths. One farmer spared us a little water at the bottom of the pail, as he was watering a pair of cows; otherwise we had to rely on water from cattle troughs in the fields. We drank the frothy, murky water, slurping it from our cupped hands and spitting out the spiky bits of straw and grass. The water smelled and tasted of cud ruminants, but it did quench our thirst. It was past the middle of August and harvest time, and the parched fields had turned to light-brown. There were planted fields in our path, so we at least had ears of grain to nibble at, as well as raw potatoes to crunch. As the wheat was ripe, we were able to separate the kernels from the husks quite easily by rubbing the spiky ears between our hands.

My sister walked up to one farmer as he was milking his cow in the barnyard. "Praise Be!," she greeted him, as he eyed us suspiciously. "Please, sir, can you spare a little milk for an undernourished boy?" Wala pointed at me, standing at the farmyard gate. The surly farmer flatly refused. "Young lady," he answered. "I would rather pour it into the gutter than give it to fanciful folk from the big city!" Those driven out of the capital were not very popular with the oblivious peasants, who derived little pride from the uprising and blamed it for the resulting German anger and harsh treatment. The revolt had, no doubt, led to more of their pigs and produce being confiscated to feed the Wehrmacht. 
Our situation had now become hopeless. We were utterly exhausted from running, from the ceaseless strain we'd been under ever since the outbreak of the uprising, and from the unbearable heat that went on and on without let-up. We couldn't see any way out of our predicament. Oh God, had we not suffered enough-would this nightmare ever end? Hungry and thirsty in the blistering summer heat, we felt all our energy ebbing away and were getting weaker and weaker by the hour. We were tottering on our feet. My knees eventually gave way, and my legs would no longer carry me. Wala experienced the same, and we dropped to the ground in a field, in the midday heat, with no shade to be had, overcome with exhaustion and with no strength to carry on. The years of struggle had finally taken their toll and pushed us to the limit.

We lost our temper with each other, which had never happened before: my only sister and I had always been close. I don't know what possessed me to start arguing with her: she was seven years older and like a mother to me. I almost blamed her for the mess we were in. We were so tired of the struggle, of running, and even of life; I wanted only to close my eyes and go to sleep. For the first time, we both felt that giving up would be a release. It could be dangerous to fall asleep in this state and in this heat, weakened by hunger and thirst and probably suffering from sunstroke, but we didn't care: all we wanted to do was to lie down and not wake up; we were done for. However, by late afternoon, when the day had cooled somewhat and we'd had a little rest, our instincts for survival took over once more. I remembered that Father had made me promise before we parted that I would never give up, nor forget, come what may. My sister and I both agreed that if we gave up now, all our struggles would have been in vain. We hugged and made up, resolving to persevere as best we could and never to give up the fight. At the very least, we owed it to our parents, who were never far from our thoughts.

We spent the night dozing intermittently, leaning against the outside wall of a barn. During the night I whispered to my sister that I was hungry to the point of starving and that I wanted to sneak inside the farm to see if I could find something to eat, perhaps some nourishing eggs, as I'd heard clucking hens in the evening before they had settled down for the night. Wala, more practical and less impulsive, restrained me: she was afraid I would disturb the farm dog and alert the farmer. We agreed that we'd had enough of the countryside and being chased off 
farms like stray dogs by unfeeling peasants. We decided to try our luck with the townsfolk instead. Surely one should be able to find a person with a heart to come to one's aid. But which town should we aim for? We had no idea where we were, nor in which direction to go.

Early the next morning, my sister said that during the night Father and Mother had appeared before her in her dreams. Seeing the predicament we were in, Father had said, "Children, be strong, you must promise to never give up." Father had always addressed us as "Children." Wala said that Father had advised her: "Children, you are going the wrong way; you must change direction and head towards Warsaw." Back to Warsaw? That was the very place we had been trying to get away from. But we never failed to take Father's advice, and could not begin now, even though this advice was only a dream. We made an early start and began to trek back in the direction Father had urged us to go. Although we were in the middle of nowhere, we knew in which direction Warsaw lay by the pillar of smoke rising to the sky above the capital. From this we assumed that the insurgents were still holding out, so we kept off the main roads where we could have encountered German patrols and army traffic heading to and from the capital. Hungry, thirsty, and totally drained, we just about managed to trudge along at a snail's pace. Like before, all we had to eat was cereal grain that we picked from the fields. But to our delight, we came across a very welcome brook in our pathor it may have been a spring - that came like a blessing from heaven. We splashed our faces thoroughly and lapped at the water like puppy dogs, together with the animals and birds that gathered there. This brook revived us and probably saved our lives; we must have been suffering from an advanced stage of dehydration since the previous day, without realising or even knowing the meaning of the word. We certainly knew what extreme thirst was like, but had no idea about dehydration and the harm it can do in just a matter of hours. After a good splash all over, we felt refreshed. Though we were reluctant to leave the watering hole and the shade of the bushes, we had to press on. After walking on and off for about another day and a half, we realised that we could not be too far away from Warsaw, judging by the dark column of smoke we were using as a marker. Having plodded along slowly but doggedly, by the middle of the next day we smelled on the gentle breeze the odour of burning, and we thought that this was as near to the hell of Warsaw as we would want to get. 
Just then, we noticed a sign along the road pointing in the direction of a place called Włochy. It rang a bell with Wala, and we liked the sound of the place, so we decided to head for it. The name rather amused us: it stands for Italy in Polish, but to us it could have been the Garden of Eden. Perhaps it was a good omen; we fantasized that this was a place where one could knock on any door and ask for a little water and maybe even a slice of bread, and not be turned away. 